\title{
Antioxidant and Antidiabetic Potential of Galing Stem Extract (Cayratia trifolia Domin)
}

\author{
Muhammad Ilyas Yusuf', Wahyuni' ${ }^{1}$, Sri Susanty ${ }^{2}$, Ruslan ${ }^{3}$, Muammar Fawwaz ${ }^{4 *}$
}

\section{Muhammad llyas Yusuf', Wahyuni', Sri Susanty ${ }^{2}$, Ruslan ${ }^{3}$, Muammar Fawwaz $^{4^{*}}$}

\section{${ }^{1}$ Faculty of Pharmacy, Universitas Haluoleo, Kendari, Southeast Sulawesi, INDONESIA. ${ }^{2}$ Department of Nursing, Faculty of Medicine, Universitas Haluoleo, Kendari, Southeast Sulawesi, INDONESIA. \\ ${ }^{3}$ Department of Mathematics, Faculty of Science, Universitas Haluoleo, Kendari, Southeast Sulawesi, INDONESIA. \\ ${ }^{4}$ Department of Pharmaceutical Chemistry, Faculty of Pharmacy, Universitas Muslim Indonesia, Makassar, South Sulawesi, INDONESIA. \\ Correspondence}

Mr. Fawwaz

Department of Pharmaceutical Chemistry, Faculty of Pharmacy, Universitas Muslim Indonesia, Makassar 90231, South Sulawesi, INDONESIA.

Phone no : +62-85-255222464

E-mail: muammar.fawwaz@umi.ac.id

History

- Submission Date: 16-01-2018;

- Review completed: 05-03-2018.

- Accepted Date: 11-05-2018

\section{DOI : 10.5530/pj.2018.4.113}

Article Available online

http://www.phcogj.com/v10/i4

\section{Copyright}

(C) 2018 Phcog.Net. This is an openaccess article distributed under the terms of the Creative Commons Attribution 4.0 International license.

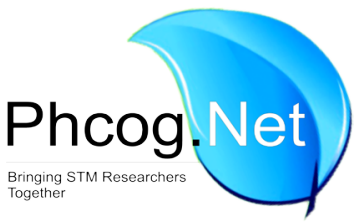

\begin{abstract}
Galing (Cayratia trifolia Domin.) have been used empirically to treat various diseases, one of them is antidiabetic. Objective: To determine the phytochemical content and the activity of the ethanol extract of the galing stem as antioxidant and antidiabetic. Method: The galing stem extract was investigated for phytochemical by Thin Layer Chromatography (TLC) and its antioxidant activity using DPPH scavenging activity assay. In vivo, antidiabetic test was conducted by animal diabetes modeling that has given streptozotocin $150 \mathrm{~g} / \mathrm{kg} \mathrm{BW}$ and $10 \%$ of sucrose solution intraperitoneally. The average level of fasting blood glucose at $307 \mathrm{mg} / \mathrm{dL}$. Mice were divided into 6 groups, normal control group, diabetes induction group, positive group (treated by glibenclamide) and treatment group consisted of three groups were treated by ethanol extract of galing stem in dose 400,500, and $600 \mathrm{mg} / \mathrm{kg} \mathrm{BW}$, respectively. Mice treated with appropriate doses of each treatment once a day for 7 days. The measuring blood glucose level was using a photometer 5010V5+. Results: The ethanol extract of galing stem contained the alkaloid, flavonoid, saponin, tannin, and triterpene. It is potential as an antioxidant with the $\mathrm{IC}_{50} 61,52 \mathrm{mg} / \mathrm{L}$ which indicated that the extract had strong antioxidant. The antidiabetic activity showed that the effect of extract 400 and $500 \mathrm{mg} / \mathrm{kg} \mathrm{BW}$ are not different significantly with glibenclamide in reducing blood glucose levels subset of the statistics ANOVA ( $p>0.05)$. Conclusion: The ethanol extract of galing steam is potent as an antioxidant due to the phytochemical content inside particularly the flavonoid compound.

Key words: Antioxidant, Antidiabetic, Galing stem, Mice, Phytochemical.
\end{abstract}

\section{INTRODUCTION}

Diabetes Mellitus (DM) is a metabolic disorder characterized by hyperglycemia and abnormal metabolism of carbohydrates, fats, and proteins that caused by decreasing insulin secretion, decreasing insulin sensitivity or both. ${ }^{1-2}$ Diabetes mellitus is a disease that causes a risk mortality/morbidity and decreasing of patients life. ${ }^{2}$ Treatments of diabetes have been conducted in various ways, such as regular exercise and diet. The treatment can also by giving of insulin or commercial antidiabetic medicines which are commonly known as synthetic drugs. This treatment is expensive and causes side effects. Some symptoms of the side effects are included bloating and diarrhea. The other side effects that may result are the increasing risk of myocardial infarction and the increased risk of cardiovascular side effects. ${ }^{2-3}$

The using of traditional medicines is safer than the modern medicines because traditional medicines have less relatively side effects than modern medicines. ${ }^{4-5}$ The number of synthetic organic chemical compounds have been available for diseases treatment, but very important to look for the other alternatives that allow for better effectiveness and therapy which are expected to have minimal side effects; the medicines extracted from plants. ${ }^{6}$ One of the plants that have been used by
Indonesian people as traditional medicine is galing (Cayratia trifolia Domin). The roots of galing have been used empirically to treat various diseases, such as poultice on boil surface. The seeds infuse and galing bulbs extract traditionally been used for diabetic patients to lower the blood sugar levels, galing also has efficacious as anti-diuretic, anti-tumor, neuralgia, and splenopathy. The bulbs commonly are used in snakebite treatment. ${ }^{7}$ Research conducted by Batra et al. ${ }^{8}$ showed that flavonoids contained by the galing roots have antidiabetic effect which improves pancreatic $\beta$-cells that have been damaged. ${ }^{8}$ However, the activity of galing stem as antidiabetic has not been tested scientifically. Therefore we are interested in conducting the antioxidant activity and antidiabetic effects of stem galing ethanol extract in mice by of streptozotocin inducing method.

\section{MATERIALS AND METHODS}

\section{Chemicals}

Ascorbic acid, 2,2-diphenyl-1-picrylhydrazyl (DPPH), streptozotocin from Sigma Chemie GmbH Aldrich. Pro analysis grades of ethanol, n-hexane, ethyl acetate, methanol, Dragendorff reagents, ammonia vapor reagent, Lieberman-Buchard reagent, $\mathrm{H}_{2} \mathrm{SO}_{4}$ 
$0.1 \mathrm{M}, \mathrm{FeCl}_{3} 1 \%$, sucrose $10 \%$, citrate buffer and TLC silica gel plate of 60 GF254 was purchased from Merck. Distilled water was obtained through a Millipore-Q50 Ultrapure water system (Sartorius). The stock solution of DPPH $(c=100 \mathrm{mg} / \mathrm{L})$ was prepared by dissolving $5 \mu \mathrm{g}$ of DPPH with $20 \mathrm{ml}$ ethanol and diluted to $50 \mathrm{ml}$. The stock solution of ascorbic acid ( $\mathrm{c}=100 \mathrm{mg} / \mathrm{L}$ ) was prepared by dissolving $5 \mathrm{mg}$ with $10 \mathrm{ml}$ ethanol and diluted to $50 \mathrm{ml}$ in the flask.

\section{Extraction}

The sample of galing stem was macerated with $96 \%$ ethanol for $3 \times 24 \mathrm{~h}$ at room temperature. Remacerated was conducted by stirring and replacing the solvent after first maserat filtering for 3 times. The filtrate was collected then concentrated by rotary vacuum evaporator at $50{ }^{\circ} \mathrm{C}$ to obtain a viscous extract. ${ }^{8}$

\section{Phytochemical screening}

Phytochemical screening was conducted by using TLC silica gel plate of 60 GF254. The Extracts were spotted on $\pm 1 \mathrm{~cm}$ from the bottom edge of the plate with the capillary tube, then dried and eluted with the eluent n-hexane: ethyl acetate: methanol. Alkaloids detected by Dragendorff reagent, flavonoids detected by ammonia vapor reagent, saponin detected by $\mathrm{H}_{2} \mathrm{SO}_{4} 0.1 \mathrm{M}$ reagent, tannins identified by $\mathrm{FeCl}_{3} 1 \%$ reagent, and terpenoids detected by a Lieberman-Buchard reagent. ${ }^{9}$

\section{DPPH radical scavenging assay}

The antioxidant activity determined by DPPH radical scavenging was using the method as described by Phang et al. The extracts with various concentrations were mixed with $1 \mathrm{~mL}$ of DPPH $(100 \mu \mathrm{g} / \mathrm{L}), 2 \mathrm{~mL}$ of ethanol, and incubated at room temperature $\left(37^{\circ} \mathrm{C}\right)$ for $30 \mathrm{~min}$. Absorbance was read at $520 \mathrm{~nm}$ using spectrophotometer (UV-2450 Shimadzu). Methanol was used as blank, and DPPH solution without addition of extract was used as a control. The sample was diluted in $1000 \mathrm{mg} / \mathrm{L}$ to provide 50, 100, 200, 400 and $800 \mathrm{mg} / \mathrm{L}$ of sample solution. Ascorbic acid was used as a standard comparison, divided into five concentrations (1, 2, $3,4$, and $5 \mathrm{mg} / \mathrm{L})$. The percentage inhibition activity was calculated as $\left[\left(\mathrm{A}^{0}-\mathrm{A}^{1}\right) / \mathrm{A}^{0}\right] \times 100$, where $\mathrm{A}^{0}$ was the absorbance of the control, and $\mathrm{A}^{1}$ was the absorbance of the extract/standard. The Inhibition Concentration $50 \%\left(\mathrm{IC}_{50}\right)$ value was determined by interpolation from non-linear regression of plot of percentage of inhibition against the concentration of extracts, which is defined as the amount of extract needed to scavenge $50 \%$ of DPPH radicals. ${ }^{10}$

\section{Animals modeling}

Animals test used are male mice in 2-3 month and 20-30 g which are healthy and behaving normally. Male mice were adapted for one week to create diabetes by streptozotocin-induced based on Body Weight (BW) with of $150 \mathrm{mg} / \mathrm{kg} \mathrm{BW}$ for a dose that diluted in citrate buffer $\mathrm{pH} 4.5$ by intraperitoneal (i.p). This test has been approved by the ethical research committee of Faculty of Medicine, Universitas Haluoleo Kendari, No: 737/UN29.20/PPM/2016.

\section{In vivo, antidiabetic assay}

Mice were acclimated to the cage for 7 days by given food twice a day and adlibitum drink, then the mice fasted for 10-12 h, and the fasted normal glucose blood level was measured by the photometer. The 30 mice were intraperitoneally given $150 \mathrm{mg} / \mathrm{kg} \mathrm{BW}$ of streptozotocin and $10 \%$ of sucrose solution to obtain mice diabetic modeling. After 2 days of the inducing, fasting blood glucose levels (glucose diabetes) of the mice were measured. If blood glucose levels of mice were increased in $>62-175 \mathrm{mg} / \mathrm{dL}$, the mice were considered to have diabetes. The 30 mice randomly were divided into 6 groups which were consisted of normal control group, diabetes induction group, positive group, and treatment group. The treatment group consisted of stem galing ethanol extract in 400, 500, and $600 \mathrm{mg} / \mathrm{kg} \mathrm{BW.}$

\section{Data analysis}

The results of the research were analyzed by using one-way ANOVA test and LSD by Statistical Product and Service Solution (SPSS) 17.0 version for Windows 8 . The statistical analysis aims to determine the differential effect as antidiabetic among three concentration of the extract and to provide clear data about the comparison effect between positive control and extract.

\section{RESULTS AND DISCUSSION}

\section{Phytochemical screening}

The extract was obtained by maceration method on galing stem. The maceration process uses room temperature to minimize the damage of bioactive compounds in the extract. The analysis done on the sample is qualitative phytochemical test by TLC method with a specific reagent. The phytochemical test aims to determine the existence of bioactive compounds that are expected to act as antioxidants or antidiabetes. The results of phytochemical tests can be seen in Table 1 .

\section{Antioxidant activity}

The parameter used for antioxidant activity is $\mathrm{IC}_{50}$ which was defined as the concentration of antioxidant that caused loss of 50\% of DPPH activity by comparison to ascorbic acid. The antioxidant activity of the extract and ascorbic acid can be seen in Table 1 .

The $\mathrm{IC}_{50}$ of the extract was $61,52 \mathrm{mg} / \mathrm{L}$ which indicated that the extract had strong antioxidant activity. The range strong antioxidant activity were ranging $50-100 \mathrm{mg} / \mathrm{L}$. The $\mathrm{IC}_{50}$ of ascorbic acid was $3.97 \mathrm{mg} / \mathrm{L}$ which indicated that it has very strong of antioxidant activity category because of its $\mathrm{IC}_{50}$ values less than $50 \mathrm{mg} / \mathrm{L}$. The strong category as an antioxidant of C. trifolia Domin, most likely due to high levels of flavonoids. It contains kaempferol, myricetin, and quercetin which is included in the group of flavonoids. ${ }^{11}$ Flavonoids can act as an antioxidant by reacting with free radicals which it is essential for maintaining the balance of oxidants and antioxidants in bodies. ${ }^{7,11}$

\section{Antidiabetic effect}

The effectiveness of ethanol extract of galing stem as antidiabetic was conducted to determine the effectiveness in decreasing blood glucose levels fastly of diabetic male mice. The 36 of male mice which 6 of the mice, as the normal group was not given treatment and 30 mice were induced by streptozotocin. The number $150 \mathrm{mg} / \mathrm{kg}$ BW of streptozotocin was injected intraperitoneally which is based on the research of Mega (2012). Streptozotocin has been successful as inducers with $50 \mathrm{mg} / \mathrm{kg}$ BW and $150 \mathrm{mg} / \mathrm{kg}$ BW; diabetic mice were obtained in 2 days after

Table 1 : Results of phytochemical screening and antioxidant activity.

\begin{tabular}{|c|c|c|c|c|}
\hline Sample & $\begin{array}{l}\text { Phytochemical } \\
\text { components }\end{array}$ & Reagent & Results & $I C_{50}(\mathrm{mg} / \mathrm{L})$ \\
\hline \multirow{5}{*}{$\begin{array}{l}\text { C. trifolia L. } \\
\text { extract }\end{array}$} & Alkaloids & Dragendorff & + & 61.52 \\
\hline & Flavonoids & Ammonia & + & \\
\hline & Saponin & $\mathrm{H}_{2} \mathrm{SO}_{4}$ & + & \\
\hline & Tanin & $\mathrm{FeCl}_{3} 1 \%$ & + & \\
\hline & Triterpen & $\begin{array}{c}\text { Lieberman- } \\
\text { burchard }\end{array}$ & + & \\
\hline Ascorbic acid & & & & 3.97 \\
\hline
\end{tabular}

$(+)$ : contain secondary metabolites 
Table 2 : Average of decreasing fasting blood glucose levels of mice based on group treatment.

\begin{tabular}{|c|c|c|}
\hline \multirow[t]{2}{*}{ Group } & \multicolumn{2}{|c|}{$\begin{array}{l}\text { Blood glucose level } \\
(\mathrm{mg} / \mathrm{dL}) \pm \mathrm{SD}\end{array}$} \\
\hline & Before treatment & After treatment \\
\hline Normal & $141.25 \pm 9.53$ & $141.25 \pm 9.53$ \\
\hline Negative control & $307 \pm 124.05$ & $307 \pm 124.05$ \\
\hline $\begin{array}{l}\text { Positive control } \\
\text { (Glibenclamide) }\end{array}$ & $196.75 \pm 28.41$ & $110.25 \pm 28.41$ \\
\hline Extract $400 \mathrm{mg} / \mathrm{kg} \mathrm{BW}$ & $149.75 \pm 41.26$ & $157.25 \pm 41.26$ \\
\hline Extract $500 \mathrm{mg} / \mathrm{kg} \mathrm{BW}$ & $158 \pm 9.01$ & $149 \pm 9.01$ \\
\hline Extract $600 \mathrm{mg} / \mathrm{kg} \mathrm{BW}$ & $350 \pm 36.57$ & $-43 \pm 31.43$ \\
\hline
\end{tabular}

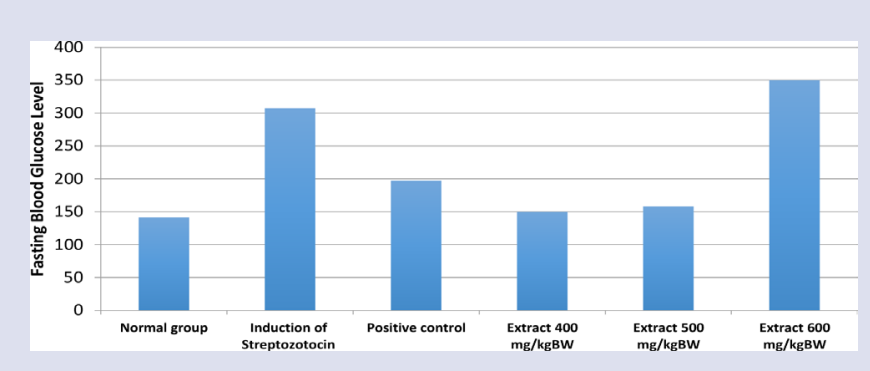

Figure 1 : Average of fasting blood glucose levels of each treatment group.

induction with $150 \mathrm{mg} / \mathrm{kg} \mathrm{BW}$ and at least 28 days after streptozotocin induction with $50 \mathrm{mg} / \mathrm{kg} \mathrm{BW.}{ }^{12}$

Streptozotocin is used as inducer because it is selective $\beta$ cell damage, so induction with streptozotocin is enough success with $90 \%$. Streptozotocin enters into the pancreatic $\beta$ cells via GLUT2 and causes DNA alkylation. DNA damage that induced by streptozotocin will activate the poly ADPribosylation. This process leads to the depletion of NAD+ and ATP reduction which will inhibit the secretion and decrease the synthesis of insulin. Streptozotocin will release a number of nitric oxide by inhibiting the activity of aconitase that effect in DNA damage which causing the Krebs cycle inhibition thereby reducing the ingress of oxygen in mitochondria which these effects severely limit mitochondria to produce ATP and cause the depletion of nucleotides in $\beta$ pancreas cell. ${ }^{8,12}$

Blood glucose levels Increasing after inducing streptozotocin were observed in $2 \times 24 \mathrm{~h}$, and the mice were given sucrose $10 \%$ solution to avoid hypoglycemia post-injection. Fasting blood glucose levels of mice were measured after 18-24 h. Before measurement of glucose blood levels, the mice fasted for 10-12 h to maintain the stability of blood glucose levels and to avoid the changes in blood glucose levels due to food intake. Measurement of the first day $(24 \mathrm{~h})$ showed that $26.6 \%$ of the mice were in diabetic which is caused by the different response of each mouse in streptozotocin. Measurement of the second day $(48 \mathrm{~h})$ showed that all mice were in diabetic.

The average of fasting blood glucose levels of mice increased to $307 \mathrm{mg} / \mathrm{dL}$ which was characterized by increasing glucose persistent blood levels. The thirty diabetic mice were randomly divided into five groups: induction streptozotocin group, the treatment groups which were consisted of positive control (treated glibenclamide), and three groups for extract treatment. Each group was orally given galing stem extract once a day for seven days. Measurement of fasting blood glucose levels was conducted on the eight days. Average of fasting blood glucose levels could be seen in Table 2.
The comparison effect as antidiabetic can be seen in Figure 1. The graph shows that the highest concentration of fasting blood glucose level is treatment by extract $600 \mathrm{mg} / \mathrm{kg}$ BW, then followed by negative control. It means there is no influence of therapy for extract $600 \mathrm{mg} / \mathrm{kg} \mathrm{BW}$. According to Pasaribu et al. (2012), increasing of concentration should be improving the responses, but the increasing of concentration of galing stem extract eventually declined the increasing of responsiveness, it was caused that accomplished concentration was not able to improve the response again. ${ }^{13}$ It often occurs in natural medicine because natural medicine contains not only a single compound but also contains a wide variety of chemical compounds. Increasing concentration, the number of chemical compounds will be increasing, so the interaction among the components can cause the effects decreasing. ${ }^{13}$ It can be concluded that the third dose $(600 \mathrm{mg} / \mathrm{kg}) \mathrm{BW}$ does not affect as antidiabetic.

Different with the concentration of extract $400 \mathrm{mg} / \mathrm{kg}$ BW show the significant effect of decreasing fasting blood glucose level, as well as $500 \mathrm{mg} / \mathrm{kg}$ BW. Both of these concentrations can decrease the level of blood glucose twice than negative control, and the ability of them little bit effective than positive control that treated by glibenclamide, although not significant based on statistical data ANOVA and post hoc LSD test. The average of decreasing fasting blood glucose level clearly seen in Table 2 . The decreasing of fasting blood glucose levels due to the containing of flavonoids, alkaloids, and saponins. Mechanism action of saponin that could help reducing blood sugar levels by inhibiting the activity of the enzyme alpha-glucosidase (the enzyme that responsible for the conversion of carbohydrates into glucose. ${ }^{14}$ Alkaloids were proved significantly to have regeneration ability for damaged $\beta$-pancreas cell. The insulin secretion increase was caused by the effect of sympathetic nerve stimulation (sympathomimetic) of alkaloid which affected the increase of insulin secretion. ${ }^{6,15}$

Study of Prameswari and Widjanarko reported that flavonoid could reduce blood glucose levels by its ability as an antioxidant, ${ }^{16}$ it could scavenge the free radicals, thereby reducing insulin resistance..$^{12,17}$ Another mechanism of flavonoids, especially quercetin was inhibiting GLUT2 of intestinal mucosa which could decrease the absorption of glucose. ${ }^{8}$ These mechanisms caused the decreasing in glucose and fructose uptake from the gut, so the blood glucose levels were decreasing. ${ }^{13,15,16}$

Glibenclamide therapy could decrease the blood glucose levels of diabetic mice by average reduction were $110.25 \mathrm{mg} / \mathrm{dL}$. The decreasing of blood glucose levels were caused by glibenclamide (class of sulfonylureas) which worked by increasing insulin sensitivity and increasing the insulin secretion of pancreas beta cells. ${ }^{12}$ Glibenclamide is only effective in diabetes mellitus type 2 which the diabetic condition was not complicated, and the beta cells are still in normal function. ${ }^{1,3}$

This study proves again that the amount of natural wealth that can be utilized in improving the quality of health, not only in the form of plants but also animals, such as the use of shrimp shells as a source of glucosamine ${ }^{18}$ and many more that can be explored, to produce a safer and high quality product.

\section{CONCLUSION}

Ethanol extract of galing stem (C. trifolia Domin.) contains secondary metabolites which are alkaloids, saponins, terpenoids, tannins, and flavonoids. Galing stem extract has antioxidant activity with a strong category. It also has antidiabetic effects at $400 \mathrm{mg} / \mathrm{kg} \mathrm{BW}$ and $500 \mathrm{mg} /$ $\mathrm{kg}$ BW which was equal to the positive control group (glibenclamide).

\section{ACKNOWLEDGEMENT}

The authors acknowledge the support received from Faculty ofPharmacy; Department of Nursing, Faculty of Medicine;and Department of 
Mathematics, Faculty of Science, Universitas Haluoleo, for their support and encouragement in carrying out his college work.

\section{CONFLICT OF INTEREST}

The authors declare no conflict of interest.

\section{ABBREVIATIONS}

ANOVA: Analysis of Variance; DPPH: 2,2-diphenyl-1-picrylhydrazyl; IC $_{50}$ : The concentration required to achieve $50 \%$ effect; LSD: Least Significant Difference.

\section{REFERENCES}

1. DEPKES RI. Pharmaceutical Care For Diabetes Mellitus. Jakarta: Directorate General of Pharmacy Community and Clinic. 2005.

2. Wells BG, Dipiro JT, Schwinghammer TL, Dipiro CV. Pharmacotherapy: A Pathophysiologic Approach Sevent edition. New York: The Mc Graw-Hill Companies. 2008.

3. Tjay TH, Rahardja K. Essential Drugs, Indications, Applicability and Side Effects ed.VI. Jakarta: Elex Media Komputindo. 2007.

4. Dalimartha S. Atlas of Medicinal Plants Indonesia. Jakarta: Pustaka Bunda. 2008;5:126-35.

5. Fawwaz M, Wahyudin E, Djide MN. The Effects of Isoflavone Soybean (Glycine max (L) Merill) Fermentation Results by Lactobacillus bulgaricus Towards in vitro, Osteoblast Cell Proliferation. International Journal of Pharm Tech Research. 2014;6(2):666-70

6. Nurulita $Y$, Dhanutirto $H$, Soemardji AA. Screening Activities And antidiabetic compounds of Water Leaves Extract Dandang Gendis (Clinacanthus nutans). Journal of Natur Indonesia. 2008;10(2):98-103.

7. Singh S, Mann R, Sharma SK. Phytochemical Analysis and Pharmacognostical Standardization of Stem of Cayratia trifolia (Linn.) Domin. International Journal of Pharmaceutical Science and Research. 2012;3(11):4503-6.
8. Batra S, Batra N, Nagori BP. Preliminary Phytochemical Studies and Evaluation of Antidiabetic Activity of Roots of Cayratia trifolia (L.) Domin in Alloxan Induced Diabetic Albino Rats. Journal of Applied Pharmaceutical Science. 2013;3(3):97-100.

9. Harborne JB. Phytochemistry Methods: Analyzing the Modern Way Guidance Plant. Bandung: Institut Teknologi Bandung Press. 1987.

10. Phang CW, Malek SNA, Ibrahim H, Wahab NA. Antioxidant Properties of Crude and Fractionated Extracts of Alpinia mutica Rhizomes and Their Total Phenolic Content. African Journal of Pharmacy and Pharmacology. 2011;5(7):842-52.

11. Sowmya S, Palanisamy $C P$, Palanirajan A, Balasubramanian $V$, Prabhakaran $P$ Deivasigamani $\mathrm{M}$, et al. Preliminary Comparative Analysis Phytochemicals Various Different Parts (Stem, Leaf and Fruit) of Cayratia trifolia (L.), Indo American Journal of Pharmaceutical Research. 2015;5(1):218-23

12. Mega K. Heating Therapy Gives no Protective Effects In Mice Diabetes Model. MSc thesis, University of Airlangga, Surabaya, Indonesia. 2012.

13. Pasaribu F, Sitorus P, Bahri S. Ethanol Extracts Test Skin Mangosteen (Garcinia mangostana L.) Against Decrease Blood Glucose. Journal of Pharmaceutics and Pharmacology. 2012;1(1):1-8.

14. Baud. Characterization, Phytochemicals Screening and Antioxidant Activity Test of Pare Fruit Extract (Momordica charantia L.) Journal of Mathematics and Natural Science Unsrad. 2014;3(1).

15. Wirasuasty IM, Wullur A, Wiyono W. Binahong Leaves Extract (Anredera cordifolia Steen.) Against Blood Glucose Levels In Rats Male Wistar strain (Rattus norvegicus) Induced by Sucrose. Pharmacon. 2013;2(1):28-34.

16. Prameswari OM, Widjanarko SB. Effects of Pandan Wangi Leaves Water Extract to Decrease Blood Glucose and Histopathology of Diabetes Mellitus Rats. Journal of Food and Agro-Industry. 2014;2(2):16-27.

17. Lenzen S. The Mechanisms of Alloxan and Streptozotocin Induced Diabetes. Diabetalogia. 2008;51(2):216-26

18. Fawwaz M, Baits M, Saleh A, Irsyaq MR, Pratiwi RE. Isolation of Glucosamine $\mathrm{HCl}$ from Penaeus monodon. International Food Research Journal. 2018.

\section{GRAPHICAL ABSTRACT}

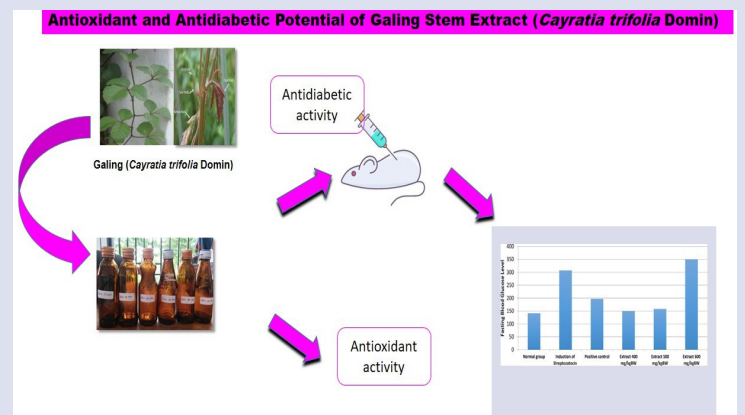

\section{SUMMARY}

1. Galing stem (C. trifolia Domin.) extract contain secondary metabolites like alkaloids, saponins, terpenoids, tannins, and flavonoids.

2. Ethanol extract of galing stem has antioxidant activity with $\mathrm{IC}_{50} 61,52 \mathrm{mg} / \mathrm{L}$ which indicated has strong activity.

3. The ethanol extract also has high potential as antidiabetic. The extract 400 and $500 \mathrm{mg} / \mathrm{kg} \mathrm{BW}$ are not different significantly with glibenclamide in reducing blood glucose levels subset of the statistics ANOVA ( $p>0.05$ )

\section{ABOUT AUTHORS}

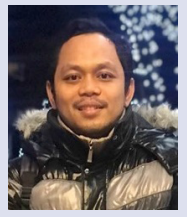

Muammar Fawwaz obtained his M.Sc degree in 2013 from Hasanuddin University, Indonesia. Currently, he is an assistant professor at Department of Pharmaceutical Chemistry, Universitas Muslim Indonesia, Makassar. He engages in the project on the medicinal compound of natural resources. Since 2017, he conducts his research as a Ph.D. student at Clinical and Analytical Sciences Laboratory, Division of Pharmaceutical Sciences, Kanazawa University (Japan). His research focuses on synthesis of the radiochemical compound as cancer imaging agent

Muhammad Ilyas Yusuf: Currently works as lecturer staff at the Department of Pharmacy Faculty of Pharmacy, Halu Oleo University, and also at the Polytechnic Bina Husada Kendari,Southeast Sulawesi, Indonesia. The last education is in Magister Immunology at Airlangga University. Lecturing subject is Pharmacology, Clinical Toxicology, Immunology, and Immunoserology. The research focuses on Pharmacology of Natural Product and Immunology.

Cite this article: Yusuf MI, Wahyuni, Susanty S, Ruslan, Fawwaz M. Antioxidant and Antidiabetic Potential of Galing Stem Extract (Cayratia trifolia Domin). Pharmacog J. 2018;10(4):686-9. 